Piotr Sobotka

Uniwersytet Mikołaja Kopernika, Toruń

psobotka@umk.pl

Magdalena Żabowska

Uniwersytet Mikołaja Kopernika, Toruń

zabowska@umk.pl

\title{
WYODRĘBNIANIE, DEKODOWANIE I KLASYFIKACJA HISTORYCZNYCH JEDNOSTEK JĘZYKA
}

Słowa klucze: historyczna jednostka języka, lingwistyka statyczna, lingwistyka dynamiczna, klasyfikacja składniowo-semantyczna części mowy, zaimki, wyrażenia metatekstowe

Keywords: historical unit of language, static linguistics, dynamic linguistics, syntactic and semantic classification of parts of speech, pronouns, metatextuals

W dwóch artykułach (por. Sobotka 2017a, 2017b) zaproponowano wprowadzenie do badań historycznojęzykowych terminu historyczna jednostka języka: omówiono w nich m.in. główne metody rekonstrukcji takich jednostek, tzn. metodę rekonstrukcji wewnętrznej i rekonstrukcji historyczno-porównawczej (Sobotka 2017a) oraz opisano sposoby odtwarzania znaczenia jednostek historycznych za pomocą narzędzi wypowiedzeniowych (struktur informacyjnych) i składniowych z uwzględnieniem nadrzędnego kryterium metod rekonstrukcji (Sobotka 2017b). Przedmiotem niniejszego artykułu jest prezentacja i zoperacjonalizowanie pojęcia historycznej jednostki języka oraz opis problemów związanych $\mathrm{z}$ wyodrębnianiem takich bytów (przede wszystkim w odniesieniu do wyrażeń nieodmiennych), a także wstępny projekt klasyfikacji dawnych jednostek nieodmiennych. Część materiałową artykułu poprzedzają przyjęte w nim podstawowe założenia teoretyczne. 
1. W badaniu języka zasadniczo stosuje się dwa typy obserwacji (na których podstawie formułuje się sądy ogólne): analityczny i syntetyczny. Zastosowanie łącznie jednego i drugiego możliwe jest jedynie w wypadku badania języków współczesnych ${ }^{1}$, ponieważ analiza, zakładająca rozłożenie elementów języka na składowe oraz wiążąca się z prowadzeniem obserwacji na kolejnych poziomach o coraz większym stopniu szczegółowości, w sposób konieczny wymaga kompetencji językowej, i to nie w jakimś ogólnym zarysie, lecz na każdym poziomie istnienia języka (od planu wyrażania po plan treści, czyli na płaszczyźnie fonologicznej, morfologicznej, leksykalnej, syntaktycznej, semantycznej i pragmatycznej). W odniesieniu do języka dawnego ujmowanego systemowo nie analizuje się danego zjawiska czy podsystemu, lecz je syntetyzuje, czyli rekonstruuje. Przede wszystkim ustala się podstawowe elementy systemu (w prezentowanym tu ujęciu: historyczne jednostki języka) i ich własności, określa się reguły ich dystrybucji, zakłada możliwe ścieżki ewolucji, ewentualnie charakteryzuje się ich kontekst i definiuje zasady ich oddziaływania z kontekstem. Taki sposób podejścia pozwala na odtworzenie na podstawie tekstów, bez dostępu do pewnych danych na temat rzeczywistych jednostek języka ${ }^{2}$, systemu jako całości. Podstawowym bowiem przedmiotem opisu badań lingwistycznych jest system języka. W formułowaniu wniosków na temat elementów systemu nie chodzi o wskazywanie różnorodnych funkcji danego wyrażenia w zależności od kontekstu, ale o wskazanie konstytuującej dane wyrażenie funkcji, którą ono spełnia niezależnie od typu tekstu lub gatunku tekstu. Także w obserwacjach historycznojęzykowych (nie tylko więc w ujęciach współczesno-synchronicznych) możliwy jest systemowy (nieizolowany) opis elementów języka. Dowodem na istnienie systemu są:

(1) dla elementów nieznaczących - reguły fonologii, a w aspekcie dynamicznym prawa głosowe i ogólne reguły analogiczne, np. prawo Kuryłowicza-Mańczaka (Kuryłowicz 1945-1949; Mańczak 1978),

(2) dla elementów znaczących - reguły tworzenia semantycznie poprawnych konstrukcji, a w aspekcie dynamicznym - regularne wzorce motywacyjne (por. Zalizniak 2008), np. 'chwycić/pojąc' $\rightarrow$ 'zrozumieć', por. pol. pojąć, ros. понять, fr. saisir, comprendre, ang. to catch .

$\mathrm{W}$ ujęciu historycznojęzykowym system (zwłaszcza w aspekcie semantycznym) może być jedynie rekonstruowany (syntetyzowany) na poziomie funkcjonalnym,

1 Model odgórno-oddolny, który przewiduje zarówno analizę, jak i syntezę, to m.in. teoria Igora Mielczuka SENS $\Leftrightarrow$ TEKST (Мельчук 1974; Mel'čuk 1982, 2001, 2012, 2013, 2015). W dużej mierze stanowi ona źródło inspiracji dla prezentowanej w tym artykule propozycji opisu jednostek historycznych.

2 Przyjmujemy za Andrzejem Bogusławskim rozumienie terminu jednostka języka (por. Bogusławski 1976, 1988, 2008). Zważywszy na to, że w żadnym wypadku o dawnych wyrażeniach nie da się z całą pewnością orzec, że są one takimi a takimi jednostkami języka, terminu jednostka języka nie da się zoperacjonalizować w odniesieniu do tekstów dawnych. 
nie zaś na poziomie pojęciowo-funkcjonalnym, nie dysponujemy bowiem metodami seryjnego wydzielania takich kategorii, jak np. agentywność, kauzatywność, następstwo, przyczynowość, współzależność itd. Jednostką opisu historycznojęzykowego nie jest jednostka języka / leksem³, lecz intuicyjnie zakładana realizacja formalno-treściowa pojęcia (jednostka historyczna) - dany (jednosegmentowy bądź wielosegmentowy) kształt służący do wyrażania rekonstruowanej treści. Historyczną jednostką języka może być wyrażenie dziedziczone (o historycznej ciągłości na gruncie jednego języka) lub zapożyczone albo utworzone w danym języku za pomocą mechanizmów derywacji bądź kompozycji czy innych tego typu przekształceń ${ }^{4}$. Również jako specyficzne historyczne jednostki języka należy traktować dziedziczone bądź zapożyczone elementy znaczące języka umożliwiające takie przekształcenia (afiksy bądź segmenty „odczuwane” jako afiksy). Jednostka historyczna ma zarówno wymiar statyczny, jak i dynamiczny. W języku wszystko się zmienia, synchronia jest zjawiskiem pozornym - to „szczególny przypadek ruchu w warunkach minimalnych zmian" (Baudouin de Courtenay 2016: 39). Na diachroniczne badanie języka składa się zatem nie tylko rekonstrukcja procesów i tendencji językowych (aspekt dynamiczny diachronii), lecz również obserwacja tego, co jest historycznie trwałe i stabilne (aspekt statyczny diachronii).

Ze statycznego punktu widzenia historyczna jednostka języka to kształt tekstowy w jego rzeczywiście semantycznym aspekcie - znaku językowego złożonego z formy i z przypisanej jej treści, powiązanej w niektórych wypadkach z zakresem nazw. Od strony dynamicznej jednostka taka ma formę niestabilną, lecz możliwą do umotywowania za pomocą: (a) zmian regularnych, (b) przekształceń analogicznych bądź (c) zmian nieregularnych spowodowanych frekwencją, zawiera ona ponadto potencjalne komponenty semantyczne i gramatyczne, często niewykrywalne w analizie statycznej (zazwyczaj tekstowej), które są z jednej strony dziedziczone od etymonu (w uproszczeniu można je nazwać komponentami etymologicznymi), z drugiej zaś odkrywane jako dziedziczone dopiero w jednostce powstałej z analizowanej jednostki historycznej, będącej etymonem dla nowego wyrażenia (w uproszczeniu określamy je komponentami asocjacyjnymi). Jednostkę historyczną języka obserwujemy zatem w trzech wymiarach: w stanie aktualnym (statycznym), w procesie zmiany, której efektem jest stan aktualny, oraz w procesie zmiany, która doprowadzi do przekształcenia stanu aktualnego w inny stan. W badaniu należy uwzględnić również tendencje dynamiczne, które są widoczne w jednostkach powstałych z jednostek wyjściowych/aktualnych (np. leksykalizację czy gramatykalizację). Podstawowymi metodami wyodrębniania historycznych jednostek języka są

3 Minimalny system tworzą cztery jednostki języka (co pozwala na zbudowanie proporcji) - w analizie współczesno-synchronicznej system jest odtwarzany na podstawie dostępnych relacji paradygmatycznych i syntagmatycznych. 
rekonstrukcja wewnętrznojęzykowa i rekonstrukcja historyczno-porównawcza (szerzej zob. Sobotka 2017a).

Do podstawowych zadań lingwistyki historycznej w jej ujęciu statycznym należy wyodrębnianie jednostek historycznych i wyróżnianie klas funkcjonalnych. Dla ujęcia dynamicznego $\mathrm{z}$ kolei zagadnienie klas prawdopodobnie ma zupełnie inne znaczenie (będzie tu raczej chodziło o przechodzenie takich a takich klas w inne). Przyjrzyjmy się pod tym względem przykładowi z Rozmyślania przemyskiego (RP):

(1) Odpowiedziawszy pan jego i rzekł jemu: «Sługo zły a leniwy! Wi<e>działeś, iże żnę ja, gdziem nie siał, a zbiram, czegom nie rozsypał. Tegodla miałeś polecić <moje pieniądze> kamsorom albo tem, co pieniądze przemieniają, a ja przyszedwszy zaprawdę wziąłbych me pieniądze z zyskiem». A zatym rzekł swym sługam: «Weźmicie od niego funt moj i dajcież temu, ktory [pięć] <dziesięć> funtow ma. Boć każdemu, ktory ma, będzie dano opwito; ktory ni ma, i to, co ma, będzie odjęto (RP 490/9-22).

Edytorzy tego zabytku, idąc za rękopisem, zdecydowali się na zapis łączny zatym, traktując to słowo jako partykułowy (?)5 wykładnik nawiązania (por. RP III: 420), por. odpowiedni fragment w rękopisie:

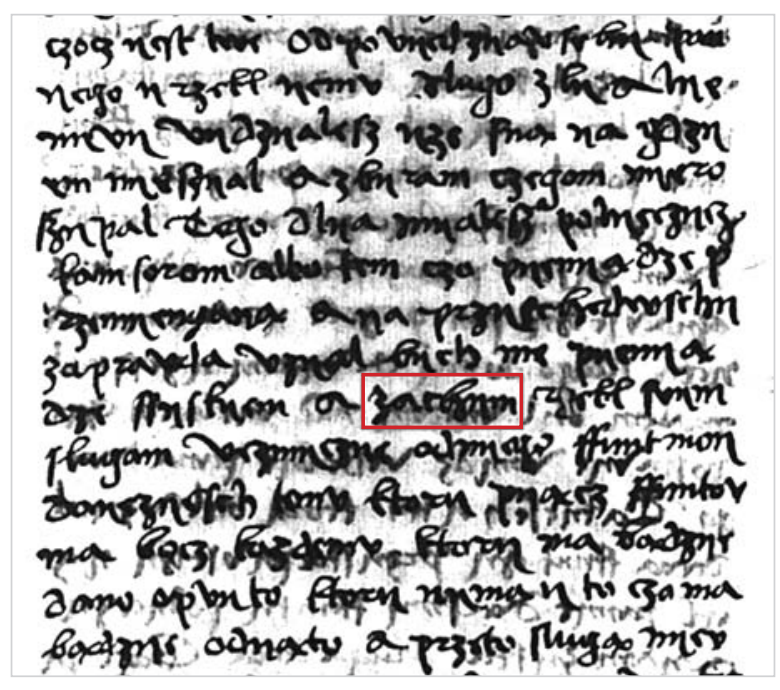

Współczesna polska partykuła zatem ma charakter wynikowy: za jej pomocą mówiący wskazuje, że gdy jest tak, że zachodzi dany stan rzeczy, to można również powiedzieć, że zachodzi inny stan rzeczy (por. Grochowski, Kisiel, Żabowska 2014: 216-218), np. Seanse byly tanie, a zatem przyciagaly wielu chętnych (NKJP). $\mathrm{Z}$ historycznego punktu widzenia $z a t e m$ to połączenie przyimka $z a$ i zaimka w na-

5 Ze względów dystrybucyjno-semantycznych nie mógłby to być spójnik: spójniki nie kookurują ze sobą, a przecież omawiane zdanie rozpoczyna spójnikowe - jak się zdaje - $a$. 
rzędniku tem/tym ${ }^{6}$. Przyimek $z a$ z narzędnikiem m.in. wyrażał w strukturze zdania stosunek przyczynowy (por. Pasoń 1976: 27-28), natomiast zaimek pełnił właściwą sobie funkcję deiktyczno-anaforyczną. Krystyna Kleszczowa (2014: 133), omawiając XVI-wieczną partykułę zatem/zatym, pisze: „źródłem partykuły zatem jest anaforyczne użycie zaimka to" i dodaje w przypisie:

$\mathrm{Na}$ anaforyczny źródłosłów polskich partykuł zwrócił mi uwagę Piotr Sobotka (2014b), omawiając analogiczne przykłady w artykule: Partykuły greckie - pochodzenie i wybrane problemy opisu.

Wyrażony wówczas przez Sobotkę sąd nie w pełni oddaje istotę rzeczy, czego ewidentne potwierdzenie odnajdujemy w przykładzie (1). Wyrażeniu zatym odpowiadają $\mathrm{w}$ paralelnych tekstach ewangelicznych łac. itaque $e^{7}$ oraz gr. oũv $v^{8}$. Pierwsze z nich nosi dość wyraźne znamiona tekstowego operatora wnioskowania, powstałego $\mathrm{w}$ wyniku połączenia zaimka ita $\mathrm{z}$ operatorem -que, drugie natomiast jest niejasnego pochodzenia, a jego wartość w języku greckim koiné również należy łączyć $\mathrm{z}$ wnioskowaniem, wyrażaniem konkluzji. Porównanie zatym $\mathrm{z}$ jego odpowiednikami łacińskim i greckim pozwala sformułować częściową hipotezę na temat funkcji tekstowej polskiego wyrażenia, lecz nie daje odpowiedzi na pytanie o jego naturę funkcjonalno-pojęciową: nie wiemy bowiem, czy mamy do czynienia ze zleksykalizowaną jednostką partykułową, czy może z konstrukcją jednostek, a jeśli to drugie, to jakie funkcje pełnią w tej konstrukcji przyimek i zaimek; tej wątpliwości zresztą nie rozwieją paralelne teksty, nawet gdyby skonstruowane były na zasadzie pełnej odpowiedniości leksykalno-gramatycznej z tekstem polskim. Interpretacja fragmentu w myśl zasad zaproponowanych wyżej (obserwacja stanu aktualnego, rekonstrukcja procesu zmiany przed stanem aktualnym i po nim) pozwala postawić hipotezę analityczną (przyimkowo-zaimkową). Wydaje się, że mamy tu do czynienia z konstrukcją, w której zaimek pełni funkcję prosentencjalną, a całość możemy rozumieć następująco: 'za tym, co zostało powiedziane [w poprzedniej wypowiedzi], powiem: .... Zaimek to ma więc charakter nie tyle anaforyczny, ile prosentencjalny i zdaje się mieć wartość referencyjno-wypowiedzeniową, jego sens można

6 Różnica między tym a tem świadczy o dawnym mieszaniu się narzędnika i miejscownika.

7 Respondens autem dominus eius dixit ei: Serve male et piger, sciebas, quia meto, ubi non semmo et congrego, ubi non sparsi; oportuit ergo te committere pecuniam meam nummulariis, et veniens ego recepissem utique quod meum est cum usura. Tollite itaque ab eo talentum et date ei, qui habet decem talenta; omni enim habenti dabitur, et abundabit; ei autem, qui non habet, et quod videtur habere, aufere Et inutilem servum eicite in tenebras exteriores; illic erit fletus et stridor dentium (Mt 25, 26-30).

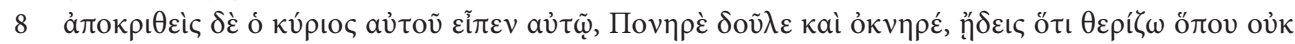

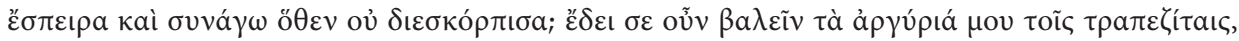

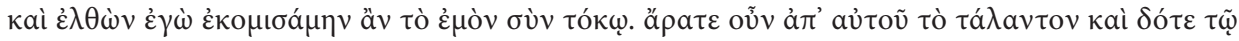

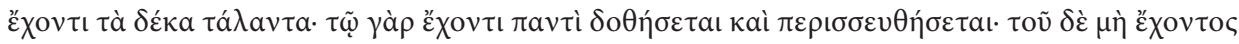

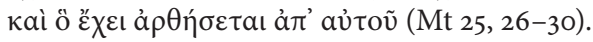


zrekonstruować jako 'to, co zostało powiedziane'. Ustalenia te opierają się również na uwzględnieniu możliwej metatekstualizacji tej konstrukcji, czego nie wykluczają XVI-wieczne przykłady użycia tego kształtu. Przyimek $z a$ z kolei nie musi pełnić funkcji przyczynowej. Może także wskazywać na współzależność zdarzeń lub ich kolejność albo zastępowanie jednych stanów rzeczy innymi ${ }^{9}$. Również z tych funkcji mogły wyewoluować sensy metatekstowe, por. ' $z a$ (= w powiązaniu $z)$ tym, co zostało powiedziane, że x, powiem y', 'za (= po) tym, co zostało powiedziane, że x, powiem y' czy ' $z a$ (= zamiast) tym, co zostało powiedziane, że x, powiem y'. Rozważany kontekst mógłby być interpretowany zgodnie ze wszystkimi wskazanymi funkcjami. Trudno rozstrzygnąć, z którą funkcją za mamy do czynienia w przytoczonym kontekście. Ostateczna weryfikacja postawionej tu hipotezy na temat funkcjonalnego statusu zatym nie jest jednakże możliwa, ponieważ nie jest możliwe odtworzenie właściwości prozodycznych omawianego fragmentu RP, nie przesądza ich także miejsce w zdaniu analizowanego wyrażenia ani jego bezpośredni kontekst leksykalny. Ustalenia Wacława Twardzika wymagałyby następującej obligatoryjnej realizacji suprasegmentalnej: A zatym 'rzekt, w proponowanym tu odczytaniu możliwe byłoby przyłożenie fakultatywnego akcentu do zaimka, por. A za'tym 'rzekł. Ponadto łączny zapis przyimka i zaimka nie przesądza jeszcze o leksykalizacji tej i innych konstrukcji, o czym też niżej.

Prezentowane tu ujęcie polega $\mathrm{w}$ pewnej mierze na projekcji tego, co w języku znane, zwłaszcza zachodzących w nim procesów, na to, co nieznane. Nie proponujemy jednak porównywania stanu współczesnego $\mathrm{z}$ minionym, bowiem $\mathrm{w}$ wypadku rzutowania (którego często nie da się uniknąć) zawsze pozostajemy w porządku współczesnym. Obiekty języka nie prowadzą żywota niezależnego od naszego ich postrzegania. Proponujemy więc statyczno-dynamiczną charakterystykę historycznej jednostki języka, biorącą w syntezie pod uwagę nie tylko dane tekstowe, wraz z uwzględnieniem obserwacji kontekstu zakładanej jednostki i jej dystrybucji w danym tekście (znalazłoby się tu również zestawienie i porównanie wszystkich wystąpień danego kształtu w tym tekście), lecz i to, co doprowadziło do powstania takiej, a nie innej jednostki o danej funkcji tekstowej, i wreszcie to, co się z nią stanie w przyszłości językowej. Uwzględniamy przy tym uniwersalne mechanizmy właściwe wszystkim etapom życia języka.

2. Wyodrębnianie i dekodowanie historycznych jednostek języka jest zawsze działaniem jednostkowym: właściwie do każdego kształtu poświadczonego w danym okresie rozwojowym języka powinno się podchodzić indywidualnie, mając na uwadze możliwość zmian formalno-treściowych. Obie czynności wymagają interpreta-

9 Zdzisława Krążyńska (2010: 57-62) wśród nieprzestrzennych konstrukcji z przyimkiem $z a$ wyróżnia m.in.: (1) quasi-przestrzenne, (2) wyrażające uprzedniość, związek, (3) czasowe. Nasze odczytanie zatem nie odbiega od możliwych staropolskich funkcji $z a$ wskazanych przez Krążyńską. 
cji i uważnej oraz możliwie jak najszerszej krytyki źródeł (czego wzór odnajdujemy m.in. w: Wanicowa 2009). Zwróćmy uwagę poniżej na kilka przykładów.

Źródło rękopiśmienne czy drukowane może zawierać błędne użycia bądź wyrażenia o cechach idiolektalnych lub specyficznych. Interpretacja danego faktu językowego winna być skonfrontowana z zamysłem autorskim. Wydawcy Żywota Pana Jezu Krysta Baltazara Opeca do wyraźnego przefto z karty $\mathrm{Q}_{5}$ dodają informację o różnicy między edycją Wietora a edycją Unglera i Sandeckiego, w której w omawianym miejscu występuje dawne i etymologicznie umotywowane przeto 'dlatego' (por. cz. proto) ${ }^{10}$ :

(2) Tamże odpowiedając, sam mowi: „O, jaciem, miły Jezu, przyczyna twej boleści, jamci zasłużenie twego zabicia i twej niewinnej śmierci”. Przezto ${ }^{8}$ wywoławając, mowi: „O, dziwnego sądu położenie, o niewymownej ${ }^{j}$ tajemnice bożej ${ }^{10}$ zrządzenie! Oto zgrzeszył niesprawiedliwy, a za to skaran sprawiedliwy, przestąpił winny, a ubit jest za to niewinny, obraził niemiłościwy, za to skazan na śmierć lutościwy" (Opec 1522/2014: 398).

${ }^{7}$ twej niewinnej - twe niewinne 1522S. ${ }^{8}$ Przezto - Przeto 1522S. ${ }^{9}$ niewymownej - niewymowne 1522S. ${ }^{10}$ bożej - boże $1522 \mathrm{~S}$.

Por. druk Wietora:

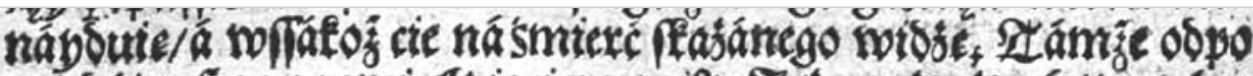

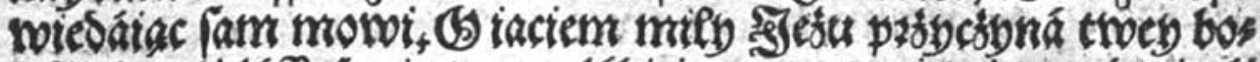

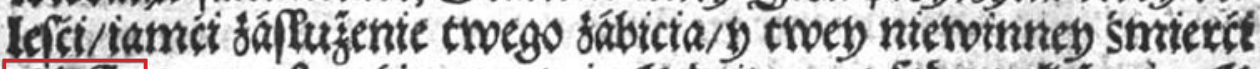

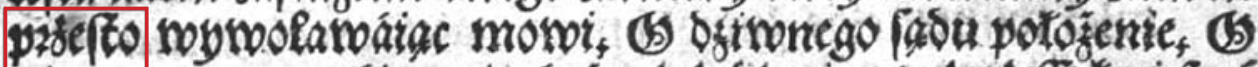

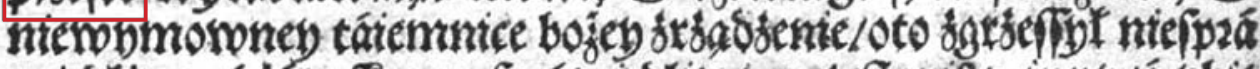

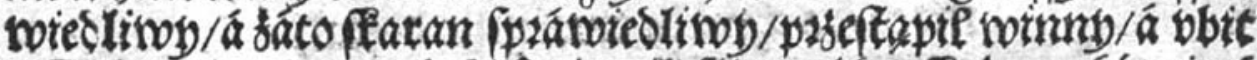

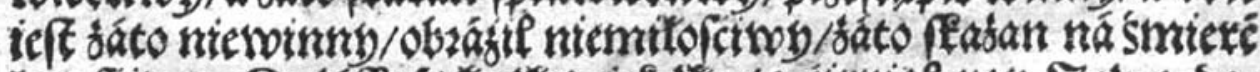

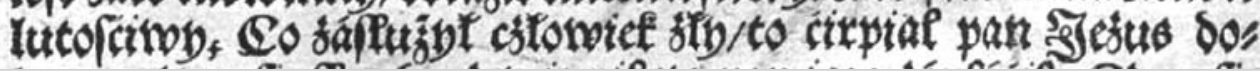

„Emendacja” Sandeckiego nie ma charakteru czysto formalnego, bowiem przeto to spójnik wnioskowania, zleksykalizowana jednostka powstała $\mathrm{z}$ połączenia przyimka ${ }^{\star}$ per 'przez' i pierwotnie wskazującego zaimka ${ }^{\star}$ to. W przykładzie (2) mamy prawdopodobnie do czynienia z deleksykalizacją przeto lub z próbą wyeksponowania jednego z członów historycznego derywatu, który - jak w przykładzie (1) należałoby uznać za konstrukcję przyimka i zaimka prosentencjalnego o znaczeniu: 'to, co zostało powiedziane'. Przy czym przez pełni tu zapewne funkcję wynikową lub wskazuje na jakiś rodzaj zależności między jednym a drugim wysłowieniem: 'ze

10 Przyimek przez jest etymologicznym złożeniem dwóch przyimków ${ }^{\star}$ per i ${ }^{\star} s$ b. 
względu na [to, co rozgłoszone ${ }^{11}$. Zauważmy, że tę interpretację wspiera kontekst z konstrukcją pleonastyczną wywoławając, mowi (szerzej na ten temat i na temat funkcji zaimków użytych przy takich układach apozycyjnych zob. Sobotka 2017b). A zatem należałoby w tym miejscu postulować istnienie dwóch historycznych jednostek języka, zapisywanych łącznie, odróżniających się od przeto, również obecnych w edycji Wietora, por. np. Przeto wielebny ociec, święty Frańciszek, nie zinąd dostapit cnot rozmaitych (Opec 1522/2014: 130), por.: 'prze + to (x), nie: prze (lub z) y', co przemawia za interpretacją przyimkowo-zaimkową omawianej konstrukcji.

W. Twardzik (1997) zauważył pewną prawidłowość związaną ze skracaniem zapisów staropolskich, której Ireneusz Bobrowski nadał następującą formułę:

Jeżeli początek następnego (po spacji) wyrazu zaczyna się tym samym znakiem (znakami), którym (którymi) kończy się wyraz poprzedni, znak (znaki) możesz zapisać tylko raz - albo na początku drugiego wyrazu, albo (rzadziej) na końcu pierwszego wyrazu (Bobrowski 2005: 382).

O lex Durani i związanych z nim trudnościach w wydzielaniu jednostek historycznych pisano wielokrotnie, dlatego ograniczymy się do przytoczenia jednej z wypowiedzi, por. np.:

Zarówno konstrukcja stworzyć ziemie, jak stworzyć z ziemie jest w średniowieczu jak najbardziej naturalna. Odczytanie zapisu z Kazań gnieźnieńskich: gest gy on szeme byl stworzil (174r/9) jako jest ji on $\boldsymbol{z}$ ziemie był stworzył jest możliwe jedynie dzięki zrozumieniu sensu zdania. Podobnie izbi ty wbostue nestiscoual (Kśw, cr 23, 37) tradycyjnie - i słusznie - czytamy $\boldsymbol{w}$ ubostwie, już nawet nie zauważając, że przyimek $w$ oraz pierwszą głoskę wyrazu ubóstwo trzeba było zobaczyć w jednym znaku graficznym (Mika 2015: 238).

Zwróćmy uwagę na jeszcze jeden przykład, w którym zaimek nie pełni swej zwyczajowej funkcji wskazywania obiektu w planie przedmiotowym. I w tym wypadku chodzi o wyodrębnienie wyrażenia, stanowiącego od strony historycznej niejako węzeł między składnią zdania a składnią wypowiedzenia. W opracowaniu Prawdziwego wyobrażenia trojga dzieci barzo strasznych i dziwnych... Jerzego Kroczaka (2007) czytamy:

(3) Kiedy ta zasłona na twarzy leżała, tedy nosa, oczu, ust nie możono widzieć i nie możono poznać, jeśli $<\mathbf{c}>\mathbf{o}$ pod tą zasłoną było.

11 W ujęciu Z. Krążyńskiej (2001: 34-39) najbliższe naszej interpretacji byłyby konstrukcje z tym przyimkiem transformujące cechę „ukierunkowanie”. 
Edytor poprawił występującą w oryginale literę $t$ na $c$ (por. Blasius 1578):

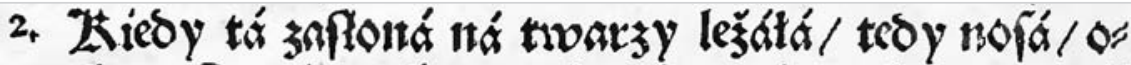

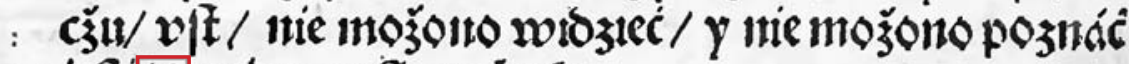 ieflito poo to zinfoita byto.}

Emendacja byłaby uzasadniona, gdyby wyraz to w sąsiedztwie operatora pytajnego jeśli 'czy' miał referencję przedmiotową. Wydaje się jednak, że należy ten zaimek odczytywać jako metatekstowy o znaczeniu 'to, co zostało wyliczone, powiedziane ${ }^{{ }_{12}}$.

Kolejną przeszkodą w rozumieniu tekstu i wyodrębnieniu składających się na niego jednostek są swego rodzaju faux amis, por. Kazanie na dzień Bożego Narodzenia z Kazań świętokrzyskich:

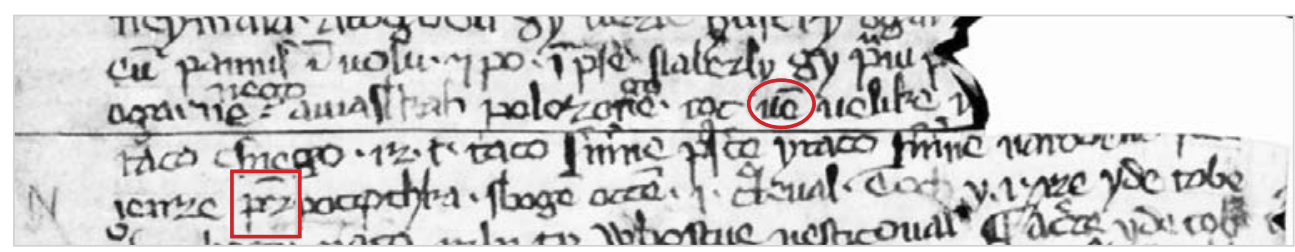

Niniejszy fragment transkrybowany bywa następująco:

(4) Naleźli ji, prawi, p<ieluszkami ... >

ogarnienego • a w jasłkach położonego • Toć wiem wielikie u<bostwo krola $>$ tako csnego • iż jeść • tako śmierne przyście i tako śmierne narodzenie • Syna Bożego,\# jenże przez początka $\bullet$ z Bogiem Oćcem • jeść • krolewał • Toć $\mathrm{i} \bullet$ jeść • iże idzie tobie (za: Mika 2012: 221-222).

Użyte w nim słowa wiem, przez przypominają współczesną formę 1. sg. praes. ind. czasownika wiedzieć oraz przyimek np. o funkcji związanej z komunikowaniem czasu trwania jakiegoś zdarzenia. Retrospektywne wyodrębnianie elementu funkcyjnego języka, niemającego przecież poza współczesnym porządkiem żadnej racji bytu, rodzi pokusę zbadania, w jaki sposób ten obiekt $\mathrm{z}$ współczesnego punktu widzenia prezentuje się w przeszłości. Powyższy przykład pokazuje, że podejście takie może być mylące. Pierwsza z niejasnych form to nie czasownik parentetyczny, lecz konektor o funkcji wyjaśniającej i uzupełniającej wcześniej przekazaną informację, na co też wskazuje kontekst całej wypowiedzi, druga natomiast, do dziś przechowywana w gwarach polskich, odpowiada współczesnemu przyimkowi bez, o czym świadczy również dopełniaczowa rekcja.

12 Zarówno za wskazanie przykładu, jak i za trop interpretacyjny dziękujemy Panu lic. Marcinowi Podlaskiemu, uczestnikowi seminarium, które Piotr Sobotka prowadzi na Wydziale Filologicznym UMK. 
Niemałą trudność wydzielania historycznych jednostek języka rodzi problem leksykalizacji i gramatykalizacji pierwotnych konstrukcji. W Żywocie Pana Jezu Krysta Opeca znajdujemy formy zapisane jako ni jedney oraz być (por. k. $\mathrm{Q}_{2} v$ ):

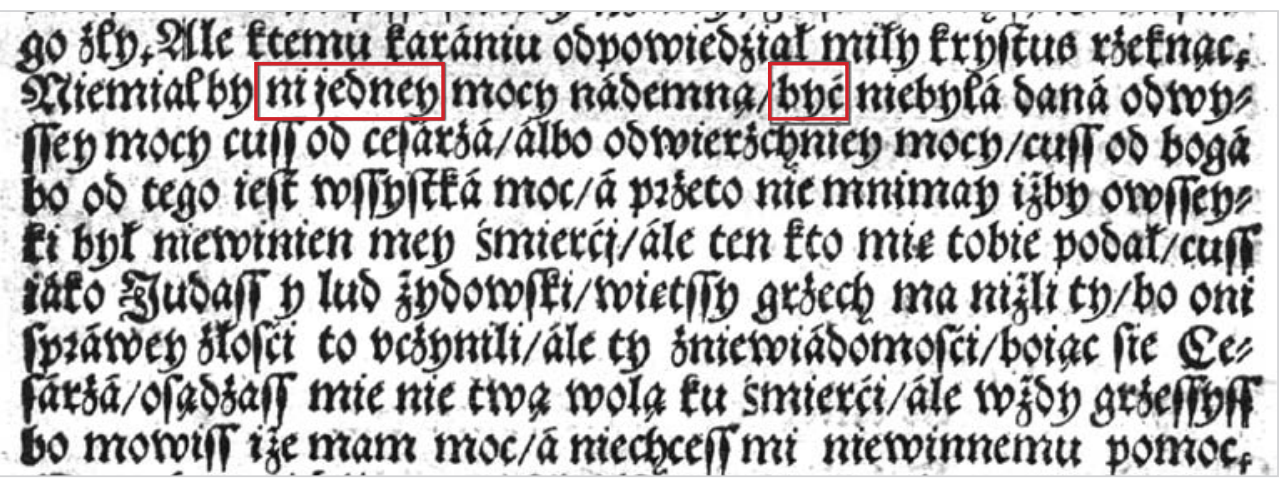

Edytorzy zabytku proponują następującą lekcję tego fragmentu:

(5) Ale k temu karaniu odpowiedział miły Krystus, rzeknąc: Nie miałby ni jednej mocy nade mną, być nie była dana od wyszej mocy, cusz od cesarza albo od wierzchniej mocy, cusz od Boga, bo od tego jest wszystka moc, a przeto nie mnimaj, iżby owszejki był niewinien mej śmierci, ale ten, kto mię tobie podał, cusz jako Judasz i lud żydowski, więtszy grzech ma niżli ty, bo oni z prawej złości to uczynili, ale ty z niewiadomości, bojąc sie cesarza, osądzasz mie nie twą wolą ku śmierci, ale wżdy grzeszysz, bo mowisz, iże mam moc, a nie chcesz mi niewinnemu pomoc (Opec 1522/2014: 388).

Istnieje subtelna różnica między ni jednej (= 'ani jednej') a nijednej (= 'żadnej'). W wydaniu Sandeckiego pierwsze z omawianych wyrażeń zostało zastąpione formą $\dot{z} a d n e$, drugie natomiast pozostało niezmienione. Jeśli uznamy, że Sandecki właściwie zrozumiał sens tej wypowiedzi, to pozorną konstrukcję ni jedney należałoby uznać za zleksykalizowany przymiotnik. Z kolei być, które oczywiście nie ma nic wspólnego $\mathrm{z}$ bezokolicznikiem o tej samej postaci, można interpretować dwojako: albo jako konstrukcję spójnika z zaimkiem osobowym w celowniku $b y$-ć(i), albo jako konstrukcję $z$ odzaimkowym operatorem -ć. Forma trzecioosobowa czasownika zdania nadrzędnego podpowiada, że mamy w tym wypadku do czynienia z odzaimkowym metaoperatorem.

Na zakończenie tego przeglądu trudności związanych z wyodrębnianiem i dekodowaniem historycznych jednostek języka zwróćmy uwagę na przykład świadczący o hipotetyczności rekonstrukcji formalno-treściowej dokonywanej w interpretacji:

(6) Żydowie jedno ji uźrą tako zabitego a tako umęczonego, kromia aczby byli kamieniem twardości, tożby sie nad nim smiłowali, ale jedwo ji uźrą, smiłują się nad nim i puszczą ji (RP 835/20-25). 
W cytowanym zdaniu pojawia się zagadkowe słowo kromia, które w rękopisie zostało zapisane jako kromya:

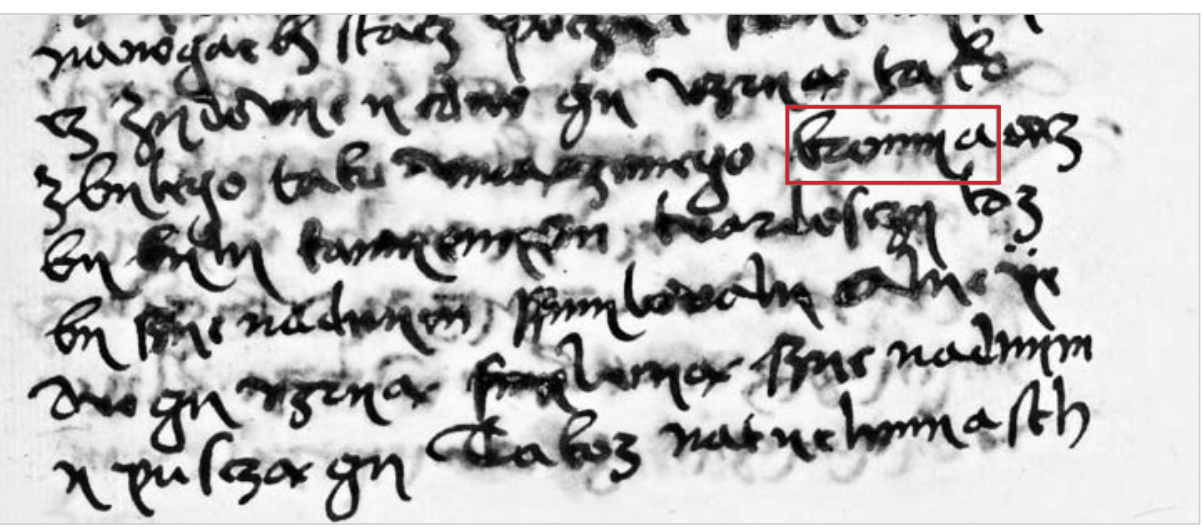

Prawdopodobnie mamy w tym wypadku do czynienia z jednostką przysłówkową lub odprzysłówkową, o czym świadczy zakończenie kontynuujące końcówkę lokatiwu $\left({ }^{*}-\check{e}\right)$. Niemniej warto porównać ten wyraz z podobnym przyimkiem o postaci krom, o którym Aleksandra Janowska (2015: 22) pisze:

Mamy więc przykłady pełnej leksykalizacji przyimków dla, prócz, krom, podług itd., gdyż nie sposób na podstawie ich budowy odczytać pochodzenia tych leksemów.

O podobnej trudności będziemy mówić i w omawianym tutaj przykładzie. Wyrażenie kromia z przykładu (6) ma swoje odpowiedniki np. w dawnym języku czeskim czy słowackim, por. tie dvere zamknuté boli, kremä kl'účovou dierkou videli, že..., a z odcieniem adwersatywnym notowane jest $\mathrm{w}$ dolnołużyckim, por. nic tak jako ja chcu, krome jako ty chces s' $^{r_{13}}$. Sens stp. kromia, którym w przykładzie (6) wprowadzane jest zdanie wtrącone, bliski jest chyba znaczeniu spójnikowemu, jak w przykładach słowackim i łużyckim, choć równie dobrze można by znaczenie tego wyrazu odtworzyć jako frazę metatekstową 'biorąc to, co mówię, na margines/skraj' (por.

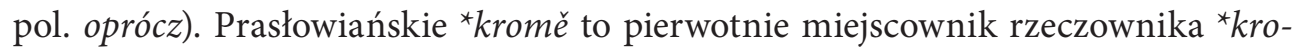
ma 'krawędź, skraj', następnie zadwerbializowany, w efekcie czego możliwe stały się przekształcenia o charakterze metatekstowym. Być może nie należy on do warstwy narracyjnej tekstu, lecz otwiera prawostronnie miejsce dla komentarza do tego tekstu.

Historyczne jednostki języka - jak to w niewielkim wymiarze i przede wszystkim w aspekcie dynamicznym zostało pokazane na kilku powyższych przykładach są rekonstruowane za pomocą wielowymiarowych narzędzi ${ }^{14}$. Mimo że proces

13 Przykłady słowacki i łużycki za: Kopečný, Šaur, Polák 1980: 377.

14 Pomijamy tu celowo opis jednostek za pomocą narzędzi interpretacji zakładanej jednostki w jej otoczeniu tekstowym, uwzględniający m.in. wszystkie wystąpienia danego kształtu w badanym 
syntezy formalno-znaczeniowej odbywa się tu w pewnym sensie w trzech wymiarach (aktualnym, przedaktualnym = etymologicznym i poaktualnym = asocjacyjnym), to jednak nie chodzi o interpretację panchroniczną, bowiem w istocie sens tych działań ogniskuje się wokół jednostki aktualnej. Historyczna ciągłość tej jednostki wymaga uwzględnienia w opisie jej komponentów dziedziczonych, które z różnych względów mogą być związane z możliwymi funkcjami sekundarnymi pełnionymi przez jednostkę, oraz komponentów asocjacyjnych, które ujawnią się dopiero w działaniu, w procesie ewolucji. Te z kolei komponenty również mają charakter sekundarny w momencie aktualnym. Historyczne jednostki języka mogą funkcjonować na różnych poziomach (zdaniowym lub wypowiedzeniowym, uwzględniającym poziom nieprzedmiotowy wypowiedzi) właśnie ze względu na ich dynamiczną labilność, co z aktualnego punktu widzenia można przedstawić za pomocą ekspozycji albo funkcji prymarnych lub sekundarnych ${ }^{15}$. Rozróżnianie obu tych funkcji odbywa się na płaszczyźnie językowej, czyli wymaga pewnych kryteriów formalnych. Wydaje się, że niektóre kategorie semantyczno-gramatyczne, jak prosentencjalność, kauzatywność, następstwo, przyczynowość, współzależność, mogą być w wypadku historycznych jednostek języka odkrywane przede wszystkim w procesie syntezy, uwzględniającym statyczny i dynamiczny aspekt diachronii.

3. Klasyfikacja jednostek języka polega na wyodrębnieniu spośród całego zasobu leksykalnego kilku bardzo ogólnych klas wyrazowych, które tworzą podstawowy poziom składników gramatycznych języka (por. Wajszczuk 2010: 15). W ujęciu wyłącznie dynamicznym stałych klas wyrazowych nie ma. Mamy tu bowiem do czynienia z ciągłym ruchem: zaimki zmieniają się w spójniki czy partykuły (por. Sobotka 2014a, 2014b), imiesłowy się adiektywizują bądź adwerbializują ${ }^{16}$, adwerbia stają się przyimkami lub partykułami itd. Nieodmienne zaimki i przysłówki chętnie nasycają się nowymi treściami bądź eksponują swoje funkcje sekundarne i zaczynają pracować na wyższych niż przedmiotowy poziomach języka (por. też Danielewiczowa 2012: 98; Żabowska 2015: 73-84). To w tej grupie obserwujemy największe zmiany, ale także wyrażenia autosyntagmatyczne odmienne podlegają takim przemianom, choć znacznie rzadziej niż wyrażenia niefleksyjne, por. podoba $\rightarrow$ podobny $\rightarrow$ podobno. Ostatnim piętrem tego procesu jest wewnętrznie zhierarchizowany poziom metatekstowy (na tym jednak nie kończy się proces zmian, ponieważ

tekście. Niemniej jednak uważamy, że dzięki takim obserwacjom możliwe jest pozyskiwanie jednej ze zmiennych służących rekonstrukcji jednostki historycznej. Ten rodzaj obserwacji wydaje się szczególnie podatny na możliwe ekstrapolowanie danych współczesnych na dawne, zwłaszcza jeśli wnioski wyciąga się na podstawie niehomogenicznych i w gruncie rzeczy nieporównywalnych źródeł, por. np. wszak w SStp oraz jednak w SPXVI i Sobotka 2015b.

15 Rozumienie funkcji za Jerzym Kuryłowiczem, por. np. Kuryłowicz 1936, 1945-1949, 1948, 1964.

16 Na temat procesów adwerbializacyjnych w językach słowiańskich P. Sobotka przygotowuje odrębne opracowania: referat na XVI Międzynarodowy Kongres Slawistów oraz książkę pt. The Slavic Adverb. Processes of Adverbialization. 
i w obszarze nieprzedmiotowym dochodzi niekiedy do przekształceń, za pomocą których możliwe jest „zdeleksykalizowanie” metatekstowe, por. prawdę mówiąc $\rightarrow$ prawdę pisząc (częste w wypowiedziach na forach internetowych), krótko mówiąc $\rightarrow$ krótko piszac). W przykładowym ujęciu dynamicznym (por. “ui -k̂nuo- 'rozciągnięty, rozprzestrzeniony' $\rightarrow{ }^{*} u i-s-o$ - 'cały' $\rightarrow{ }^{\star} v b \chi z$ 'ts.' $\rightarrow{ }^{\star} v b x a k o \rightarrow v$ v̌ak/wszak) otrzymujemy być może wpisującą się w pewną tendencję ścieżkę zmian: zaimek $\rightarrow$ konektor (zob. niżej) $\rightarrow$ partykuła spajająca. Weryfikacja tej drogi przekształceń kategorialnych i ewentualne jej potwierdzenie innymi przykładami wymagają ścisłego powiązania badań dynamicznych ze statycznymi. Jednak już na podstawie zaprezentowanych wyżej przykładów można powiedzieć, że zaimkowość pierwotnego wyrażenia w tym łańcuchu przemian musiała być wzbogacona o jakieś komponenty epistemiczno-emfatyczne, które częściowo dają się zrekonstruować dzięki analizom zaimkowych $a k$-formacji (por. Sobotka 2015a, 2015b).

Klasyfikowanie historycznych jednostek języka ze statycznego punktu widzenia badań diachronicznych tylko częściowo może nawiązywać do podobnych działań przedsiębranych w analizach współczesnych jednostek języka. Całkowita adaptacja jednego spośród czterech głównych modeli podziału na części mowy jest niemożliwa. W modelu semantycznym (por. np. Szober 1923; Milewski 1965) podstawowe piętro podziału opiera się na kryterium samodzielności semantycznej (jednostki języka dzieli się na autosemantyczne i synsemantyczne), w modelu fleksyjno-dystrybucyjnym (np. Saloni 1974) podstawowym wyznacznikiem działu jest odmienność wyrażeń języka, w modelu składniowym (Laskowski 1984; Wróbel 1996; Zaron 2009) pierwsze piętro klasyfikacji opiera się na odróżnieniu wyrażeń wchodzących w jakiekolwiek relacje składniowe z innymi (syntagmatyki, wśród których znajdują się autosyntagmatyki i synsyntagmatyki) od wyrażeń poza związkami składniowymi (niesyntagmatyki), natomiast w modelu funkcjonalno-semantycznym (por. Wajszczuk 1997, 2005, 2010) głównym kryterium jest otwieranie jakiejkolwiek pozycji (leksemy vs paraleksemy) oraz otwieranie pozycji nacechowanych semantycznie bądź wchodzenie na takie pozycje przez jednostkę języka (syntaktemy vs parataktemy).

Klasyfikacja historycznych jednostek języka ze względu na fragmentaryczność danych zarówno semantycznych, jak i gramatycznych winna opierać się na kryterium semantycznym wspieranym przez kryterium syntaktyczno-funkcjonalne. W wypadku tzw. tradycyjnego podziału semantycznego nie da się wprowadzić satysfakcjonujących rozróżnień w stosunku do nieodmiennych części mowy, nie jesteśmy w stanie m.in. przy nieoczywistych i niekompletnych kontekstach systemowo odróżniać przysłówka od partykuły czy spójnika, przysłówka od przyimka itp. (zazwyczaj robimy to intuicyjnie). Adaptacja podziału funkcjonalno-semantycznego Jadwigi Wajszczuk również wymaga wprowadzenia wielu korektur wynikających z ograniczeń interpretacyjnych dawnego materiału. Przyjrzyjmy się uproszczonemu modelowi częściowo inspirowanemu klasyfikacją J. Wajszczuk (2010), uwzględniającemu przede wszystkim miejsce wyrażeń nieodmiennych w całym zasobie leksykalnym oraz wyznaczającemu ich typy: 


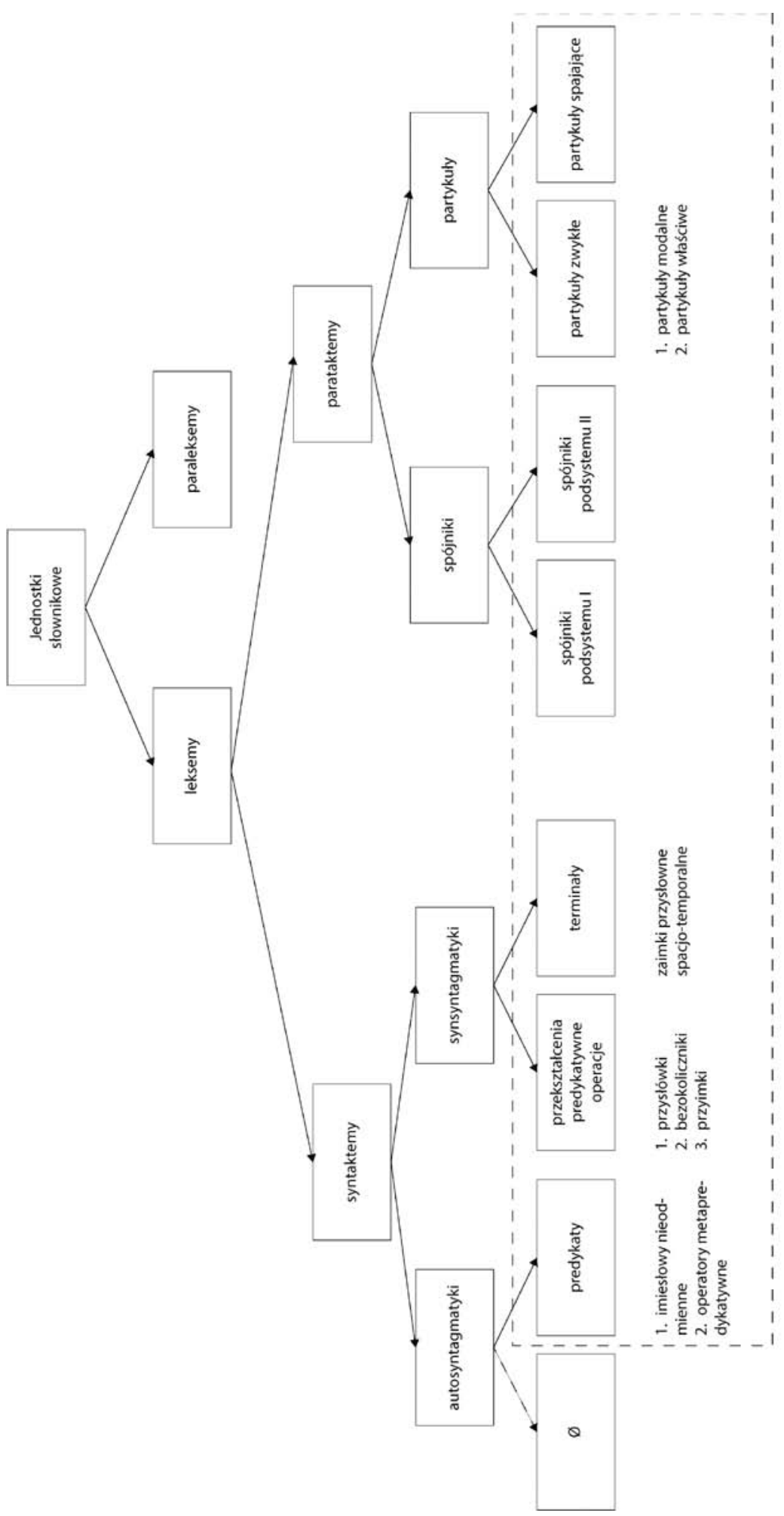


Wadą tego podziału w ewentualnej próbie dostosowania go do badań historycznojęzykowych okazuje się jego szczegółowość i charakter analityczny, który wymaga badawczego podejścia odgórnego, niemożliwego w całej rozciągłości - jak to zostało powiedziane wyżej - do zastosowania na materiale stanowiącym dla nas zagadkę - na palimpseście, którego kanonicznej warstwy nie sposób ustalić. Można jednak, wychodząc od konkretnych kategorii, przetestować podejście oddolne oparte na syntezie, w której każdą z kategorii definiuje się na podstawie kryterium funkcjonalnego. W stosunku do klasyfikacji „synchroniczno-funkcjonalnych” jednostek języka klasyfikacja historycznych jednostek języka z jednej strony musi być uproszczona, z drugiej zaś powinna przewidywać miejsce dla „pośrednich”, czyli niejasnych interpretacyjnie bytów tekstowych, które za Danešem (1985: 146-186) będziemy określać jako restryktory, kontekstualizatory i konektory.

Zakładany zasób nieodmiennych kategorii leksykalnych to: nieodmienne participium, metaoperator, przysłówek, infinitivus, przyimek, zaimek niefleksyjny, spójnik, partykuła, restryktor, kontekstualizator, konektor ${ }^{17}$. Dla części użyć tych jednostek w ujęciu historycznym rodzaj zdań, w których występują, nie jest relewantny, dla innych $\mathrm{z}$ kolei jest. $\mathrm{W}$ pierwszym wypadku będziemy mieli do czynienia $\mathrm{z}$ różnymi formalizacjami tej samej relacji semantycznej, w drugim zaś - z użyciem niezależnym konstrukcji składniowej jako całości (np. a.c.i.). Ponadto niejednokrotnie trudno - jak to pokazują konkretne przykłady - oddzielić na materiale historycznym zwykłe użycie np. participium i tym samym uznanie tego kształtu za formę czasownika, a nie jednostkę, czy infinitivu od: w pierwszym wypadku np. konstrukcji pleonastycznej z participium jako koniecznym elementem (zob. problematyczny - mimo zaproponowanej tu interpretacji - przykład (2)) czy w drugim np. od układu zbliżonego do nominativus cum infinitivo jako wykładnika modalności epistemicznej wahania, zawieszenia asercji, por.:

(7) Jesus miły dzieciątko widział sie k niem rękę podnosić a przymować ich dary a podniowszy swą rękę prawą k niem, jakoby je żegnając i weźrał na nie (RP 77, 7-11).

Interpretacja n.c.i. w powyższym zdaniu jest nieoczywista, ponieważ orzeczenia widzieci sie, choć spełniającego semantyczne wymogi składni n.c.i., nie można od strony gramatycznej traktować jako bezspornie biernego, jest to bowiem użycie medio-pasywne, a ponadto szyk omawianego zdania nie odpowiada zwyczajowemu szykowi n.c.i., między agensem czynności widzenia się a infinitivem występuje tu cały szereg innych składników: referencjalne uszczegółowienie agensa, orzeczenie

17 Ograniczenie zakresu analizowanych jednostek do wyrażeń nieodmiennych dzieli zaimki na odmienne i nieodmienne, które funkcjonalnie mogą być jednorodne, por. też stopniowanie tradycyjnie rozumianych przysłówków. Mimo to nieodmienność w ujęciu semantyczno-funkcjonalnym jest istotnym kryterium klasyfikacji ze względu na to, że wyrażenia nieodmienne nie tworzą dwustronnych związków składniowych, więc wymagają innego sposobu syntezy niż poprzez opis zależności syntaktycznych z innymi elementami zdania. 
i dopiero fraza infinitywna, ale z wyeksponowanymi na pierwszej i drugiej pozycji składnikami adiunktywnymi. Trudno też powiedzieć, czy pisarz Rozmyślania... znał ten łaciński wzorzec składniowy z jego interpretacją modalną. Niemniej jednak, gdyby przedstawiona hipoteza była trafna, to $\mathrm{w}$ zdaniu Jezus najpierw zdaje się podnosić ręce i przyjmować dary (jakkolwiek było to cudowne dziecko, to zaraz po urodzeniu chyba nie miało ono tyle siły, aby unieść „złoto, mirrę i kadzidło”), a dopiero potem rzeczywiście podnosi rękę i błogosławi trzem królom ${ }^{18}$.

Problem oddzielenia formy jakiejś odmiennej jednostki od nieodmiennej jednostki historycznej, pochodnej od tej formy, jest bardzo złożony i na obecnym etapie badań chyba niemożliwy do systemowego rozstrzygnięcia. W materiale historycznym będziemy mieli zatem równokształtne participia-formy i participia-jednostki, odmienne zaimki i wtórne spójniki pochodne od zaimków itd. W każdym takim wypadku należy dokonać interpretacji danego wyrażenia z uwzględnieniem faktu, że status bycia jednostką przysługuje tylko tym kształtom, które uznamy za symetryczne od strony formalnej i funkcjonalnej zarazem.

Każdą z wymienionych wyżej kategorii formalno-treściowych definiujemy za pomocą charakterystyki funkcjonalnej, która w tym miejscu jest prezentowana z konieczności jedynie skrótowo, bez jej rozwijania i szczegółowego opisu przykładów:

Zestaw wskazanych klas nie pokrywa się z innymi propozycjami podziału wyrażeń nieodmiennych (por. np. Grochowski 1984), nie jest bowiem podziałem gramatycznym na tak zwane klasy części mowy, lecz wyróżnioną na podstawie kryteriów logiczno-funkcjonalnych siatką wszystkich możliwych kategorii funkcjonalno-semantycznych, do jakich mogą należeć wyrażenia zarówno dawne, jak i współczesne. A zatem przykładowo relatory znajdą się w kategorii restryktorów, a korelaty zaimków względnych w kategorii zaimków niefleksyjnych, natomiast operatory pytań rozstrzygnięcia będą konektorami. Wydaje się natomiast, że pozostające poza tym ujęciem operatory trybu i modyfikatory deklaratywności można interpretować jako wyrażenia stanowiące efekt działań nadawcy na wyrażeniach, które podstawowo pełnią inne uwzględnione tu funkcje, por. ale $\dot{z}, g d z i e \dot{z}$, oby. Nasza klasyfikacja nie uwzględnia metakomentarzy w rodzaju współczesnych polskich by tak rzec, co się $t y c z y$, których pojawienie się $\mathrm{w}$ tekście związane jest $\mathrm{z}$ aktualną realizacją tego, co chce powiedzieć nadawca. Ponadto status tego typu wyrażeń (jednostka językowa, użycie, operacja) nie został dotychczas konkluzywnie rozstrzygnięty w literaturze przedmiotu ${ }^{19}$.

18 Tę hipotezę wspierają pośrednio dwa fakty. Po pierwsze, w odpowiedniku łacińskim omawianego fragmentu występuje bierna forma czasownika videbatur, por. Iesus puer videbatur manus elevare, a po drugie, Felix Keller, tłumacząc ten fragment na niemiecki, użył - zapewne zgodnie z sugestiami Wacława Twardzika - czasownika modalnego scheinen 'wydawać się', por. Das liebe Jesuskind schien die Hand zu ihnen zu heben und ihre Gaben anzunehmen (por. RP I: 151). 


\begin{tabular}{|c|c|c|}
\hline $\begin{array}{c}\text { Kategoria } \\
\text { funkcjonalna }\end{array}$ & Charakterystyka funkcjonalna & Przykład użycia \\
\hline $\begin{array}{l}\text { nieodmienne } \\
\text { participium }\end{array}$ & $\begin{array}{l}\text { jednostka odczasownikowa, otwiera } \\
\text { miejsce prawostronnie, dziedziczona } \\
\text { od czasownika strona nie ma charakte- } \\
\text { ru relewantnego }\end{array}$ & $\begin{array}{l}\text { A jako sa przyszli ku wrotom mieskiem, } \\
\text { uźrzeli niosąc umarłego jedynego syna } \\
\text { matki swej, a ta była wdowa a tegoż } \\
\text { istnego syna nasilnie płakała } \\
\text { (RP 220/12-16) } \\
\text { (por. Petrov, Twardzik 2014) }\end{array}$ \\
\hline metaoperator & $\begin{array}{l}\text { determinant predykatu, odnoszący się } \\
\text { do obiektu językowego i do nadawcy, } \\
\text { w przeciwieństwie do przysłówka } \\
\text { otwiera miejsce np. dla przymiotnika } \\
\text { czy infinitivu itd. (tym samym np. } \\
\text { staropolski intensyfikator barzo nie } \\
\text { zostanie uznany za przysłówek) }\end{array}$ & $\begin{array}{l}\text { A gdy sie to przedanie stało w Jerusalem, } \\
\text { to było prawie } w \text { ten czas, } w \text { ktory byt } \\
\text { Bog światłość stuneczna stworzyt } \\
\text { (RP 516/14-17) }\end{array}$ \\
\hline przysłówek & $\begin{array}{l}\text { determinant czasownika (określa } \\
\text { czasownik lub jest do czasownika do- } \\
\text { dawany jako jego „dookreślnik”, choć } \\
\text { czasownik nie wymaga przysłówka } \\
\text { i nie otwiera dla niego miejsca, a zatem } \\
\text { przysłówek niejako wywołuje cza- } \\
\text { sownik, wymagając czasownikowego } \\
\text { „uzupełnienia”) }\end{array}$ & $\begin{array}{l}\text { a nie poznaliście jego, ale ja znaje jej, pa- } \\
\text { kli rzku: Nie z<n>aje jego, będę podobien } \\
\text { wam łgacz... (EwKReg } 42 \text { za: SStp) } \\
\text { (nb. przykład trudny do interpretacji, } \\
\text { wydaje się, że użycie pakli w tym zdaniu } \\
\text { nosi wyraźne ślady czeskie, wszystkie } \\
\text { polskie konteksty wskazują wg A. Sło- } \\
\text { body na użycia spójnikowe w zdaniach } \\
\text { warunkowych (zob. Pawelec 2015: 106)) }\end{array}$ \\
\hline infinitivus & $\begin{array}{l}\text { determinant czasownika, otwierający } \\
\text { miejsce prawostronnie z formalną } \\
\text { blokadą miejsca lewostronnego, choć } \\
\text { z możliwą lewostronną kookurencją } \\
\text { przypadka, np. accusatiwu (por. skład- } \\
\text { nia a.c.i.), nominalny, nieodmieniający } \\
\text { się derywat czasownikowy }\end{array}$ & $\begin{array}{l}\text { Tako na środę obiecał sie przy nich } \\
\text { być a oni wszytcy mieli wielikg radość } \\
\text { (RP 496, 23-25) }\end{array}$ \\
\hline przyimek & $\begin{array}{l}\text { (sub)morfem, otwiera prawostronnie } \\
\text { miejsce dla końcówki przypadka, } \\
\text { wskazując na relację między obiektami }\end{array}$ & $\begin{array}{l}\text { Studnia była blisko Nazareta, } \boldsymbol{k} \text { niejże } \\
\text { chodziasze często <Jesus> a nosił wodę } \\
\text { swej matce (RP 123/3-5) }\end{array}$ \\
\hline $\begin{array}{l}\text { zaimek } \\
\text { niefleksyjny }\end{array}$ & $\begin{array}{l}\text { prymarny lub wtórny determinant } \\
\text { referencjalny spacjo-temporalny lub } \\
\text { prosentencjalny }\end{array}$ & $\begin{array}{l}\text { Jesus miłe dziecię wynidąc sam s } \\
\text { miasta ni miat nijednego nagabania od } \\
\text { onego źwierzęcia, ale jako sie k niemu } \\
\text { przyb<l>iżyt, tako lew poklęknąwszy na } \\
\text { swa kolana dał jemu chwałe, a gdzie-on- } \\
\text {-koli przyszedt, tu naśladując lizał jego } \\
\text { stopy (RP 138/5-11) } \\
\text { (nb. możliwe do interpretacji jako } \\
\text { zaimek niefleksyjny wyrażenie tako jest } \\
\text { prawdopodobnie konektorem) }\end{array}$ \\
\hline spójnik & determinator prawo- i lewostronny & $\begin{array}{l}\text { Ten isty obłok s nimi szedt, gdziekolwiek } \\
\text { oni szli, a gdzie stali albo siedzieli, to on } \\
\text { takież nad nimi stał (RP 87, 16-19) }\end{array}$ \\
\hline
\end{tabular}




\begin{tabular}{|c|c|c|c|}
\hline \multicolumn{2}{|c|}{$\begin{array}{c}\text { Kategoria } \\
\text { funkcjonalna }\end{array}$} & Charakterystyka funkcjonalna & Przykład użycia \\
\hline \multicolumn{2}{|c|}{ partykuła } & wyrażenie dorematyczne & $\begin{array}{l}\text { A wrociwszy sie lepak }<\text { do dzieciattka }> \\
\text { dali sa jemu chwatę a pokłoniwszy sie } \\
\text { jego matce } z \text { wielikiem weselim... } \\
\text { (RP 77/22-24) }\end{array}$ \\
\hline \multirow{3}{*}{ 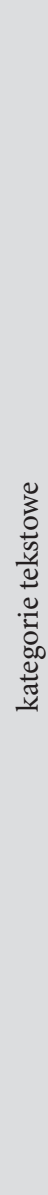 } & restryktor & $\begin{array}{l}\text { ogranicza siłę wypowiedzi do tego, co } \\
\text { jest objęte restryktorem (pseudospój- } \\
\text { nik ze znaczeniem predykatywnym) }\end{array}$ & $\begin{array}{l}\text { Maryja dziewica ostawszy }<\ldots>\text { poczęła } \\
\text { w swym żywocie }<\text { Boga }>\text {, jen }<\text { kroluje }> \\
\text { na niebie, na ziemi i } w \text { morzu, teże stwo- } \\
\text { rzył wszytki rzeczy < ... }>(\operatorname{RP} 51 / 21-23)\end{array}$ \\
\hline & $\begin{array}{l}\text { konteks- } \\
\text { tualizator }\end{array}$ & $\begin{array}{l}\text { wiąże zdanie z kontekstem (wyrażenie, } \\
\text { podobnie jak dwie pozostałe kategorie } \\
\text { tekstowe, o niejasnym statusie; zazwy- } \\
\text { czaj słowa tego rodzaju klasyfikuje się } \\
\text { jako przysłówki, przysłówki dozda- } \\
\text { niowe, spójniki lub partykuły, łączą } \\
\text { bowiem cechy tych czterech kategorii) }\end{array}$ & $\begin{array}{l}\text { „Miły synku, wspomieni na to, iżci ciebie } \\
\text { jednego mam, a tė̇ na ony słowa, ktorem } \\
\text { ja od ciebie słyszała, iżem przez boleści } \\
\text { być miała, też dzisia zbyć nie mogę. } \\
\text { Ślubowałeś, iżbych była petna miłości, } \\
\text { a wszakom w szwej żałości petna. Obie- } \\
\text { całeś przy mnie być, a dziś mię chcesz } \\
\text { samę zostawić w wielikim udręczeniu, } \\
\text { bo wim, iże twe słowo zasie ić nie może; } \\
\text { podobnie ziemi i niebu przeminać sie } \\
\text { niżli twemu słowu (RP 502/8-20) } \\
\text { (nb. pierwszy z tych kontekstualiza- } \\
\text { torów W. Twardzik interpretuje jako } \\
\text { spójnik) }\end{array}$ \\
\hline & konektor & $\begin{array}{l}\text { łączy nie tyle składniowo, ile } \\
\text { semantycznie zdania z tekstem } \\
\text { (por. spójnik niewłaściwy, partykuła } \\
\text { niewłaściwa, przysłówek w funkcji } \\
\text { łączącej, modalizator) }\end{array}$ & $\begin{array}{l}\text { Kiedyż jest to miły Jesus mowił a nikt } \\
\text { jemu nie [o]dpowiedział, tedy poczęli } \\
\text { mowić niektorzy Jerosolimianie rzekąc: } \\
\text { „Wszako to jest, ktoregoż szukaja ubić. } \\
\text { Owa już jawnie mowi a nic jemu nie } \\
\text { mowia. Zaprawdę abo sa poznały nasze } \\
\text { ksiązęta, iże to jest krystus? Ale tego } \\
\text { wimy, skąd jest, a krystus kiedy przydzie, } \\
\text { nikt nie wie, skąd będzie” } \\
\text { (RP 457/10-20) } \\
\text { (nb. Alina Kępińska (2015: 167-184) } \\
\text { interpretuje abo jako partykułowy ope- } \\
\text { rator pytania rozstrzygnięcia) }\end{array}$ \\
\hline
\end{tabular}

4. Językoznawstwo historyczne w wielu aspektach różni się od językoznawstwa opisowego, m.in. przedmiotem badań i związaną z nim terminologia. Zależność „analiz" historycznojęzykowych od teorii wypracowywanej na gruncie synchronicznym może przynosić wielorakie korzyści, lecz może również upraszczać sposób widzenia przedmiotu opisu. Językoznawca historyczny, zanim przystąpi do pracy, winien wpierw poprawnie wyodrębnić obiekt swych badań, co wydaje się jednym z najtrudniejszych zadań lingwistyki zorientowanej na rekonstrukcję przeszłości języka. 


\section{Literatura}

Baudouin de Courtenay J., 2016, Autobiogram, [w:] Materiały do dziejów polskiego językoznawstwa, t. 2: Jan Baudouin de Courtenay. Teksty mniej znane, wybór i oprac. M. Skarżyński, „Biblioteka LingVariów”, t. 21, Kraków, s. 23-57.

Blasıus J.T., 1578, Prawdziwe wyobrażenie Troyga dzieći barzo strasznych, ktorym podobne nie wiem aby kiedy były widziane na świećie..., Wrocław.

Bobrowski I., 2005, Lex Durani, „Polonica” XXIV-XXV, s. 382-383.

BogusŁawski A., 1976, O zasadach rejestracji jednostek języka, „Poradnik Językowy” nr 8, S. 356-364.

BogusŁaWski A., 1988, Preliminaria gramatyki operacyjnej, „Polonica” XIII, s. 163-223.

BogusŁaWsKi A., 2008, Semantyka, pragmatyka. Leksykografa głos demarkacyjny, Warszawa.

DANeš F., 1985, Věta a text. Studie ze syntaxe spisovné češtiny, Praha.

Danielewiczowa M., 2012, W głąb specjalizacji znaczeń. Przysłówkowe metapredykaty atestacyjne, Warszawa.

Grochowsкi M., 1984, Projekt klasyfikacji syntaktycznej polskich leksemów nieodmiennych, „Polonica” X, s. 73-97.

Grochowski M., Kisiel A., Żabowska M., 2014, Słownik gniazdowy partykuł polskich, Kraków.

JANOwsKa A., 2015, Kształtowanie się klasy polskich przyimków wtórnych, Katowice.

KĘPIŃsKa A., 2015, Polskie operatory pytajne w ujęciu diachronicznym, Warszawa - Katowice.

KleszczowA K., 2014, Zaimkowy rodowód wybranych partykut, [w:] A. Moroz, P. Sobotka, M. Żabowska (red.), Maiuscula linguistica. Studia in honorem professori Matthiae Grochowski sextuagesimo quinto dedicata, Warszawa, s. 131-140.

KopeČnÝ F., ŠAUR V., POLÁK V., 1980, Etymologický slovník slovanských jazykü. Slova gramatická a zájmena, t. 2: Spojky, častice, zájmena a zájmenná adverbia, Praha.

KrążYŃsKa Z., 2001, Staropolskie konstrukcje z przyimkami. Cz. II (po, przez, prze, mi(e)mo, nad, wz, pod, przed, za, o, miedzy + acc.), Poznań.

KrążYŃska Z., 2010, Staropolskie konstrukcje z przyimkami. Cz. IV (nad, pod, przed, za, miedzy, z + instr., o, przy, na, w + loc.), Poznań.

Kroczak J. (red.), 2007, Staropolskie przepowiednie i mirabilia, „Bibliotheca Curiosa”, t. 2, Wrocław.

KuryŁowiCz J., 1936, Dérivation lexicale et dérivation syntaxique (Contribution à la théorie des parties du discours), „Bulletin de la Société de Linguistique de Paris” 37 (110), s. 79-92.

KuRYŁOWICZ J., 1945-1949, La nature des procés dits „,analogiques”, „Acta Linguistica” 5, nr 1, S. $15-37$.

KuryŁowicz J., 1948, Zagadnienie klasyfikacji przypadków, „Sprawozdania z Czynności i Posiedzeń Polskiej Akademii Umiejętności” 49, nr 9, s. 475-478.

KuryŁowicz J., 1964, The Inflectional Categories of Indo-European, Heidelberg.

LASKOwski R., 1984, Funkcjonalna klasyfikacja leksemów: części mowy i kategorie imienne, [w:] R. Grzegorczykowa, R. Laskowski, H. Wróbel (red.), Gramatyka współczesnego języka polskiego. Morfologia, Warszawa, s. 26-37, 149-169.

MańczaK W., 1978, Les lois du développement analogique, „Linguistics” 205/16, s. 53-60, [on-line:] https://doi.org/10.1515/ling.1978.16.205.53.

MeL'Čuk I.A., 1982, Lexical Functions in Lexicographic Description, „Proceedings of the Annual Meeting of the Berkeley Linguistics Society" nr 8, s. 427-444, [on-line:] http:// dx.doi.org/10.3765/bls.v8io.2038. 
Mel'čuk I.A., 2001, Communicative Organization in Natural Language: The Semantic-communicative Structure of Sentences, Amsterdam - Philadelphia.

Mel'Čuk I.A., 2012, Semantics. From Meaning to Text. 1, Amsterdam - Philadelphia.

Mel'Čuk I.A., 2013, Semantics. From Meaning to Text. 2, Amsterdam - Philadelphia.

Mel'čuk I.A., 2015, Semantics. From Meaning to Text. 3, Amsterdam - Philadelphia.

Mika T., 2012, „Kazania świętokrzyskie” - od rękopisu do zrozumienia tekstu, Poznań.

Mika T., 2015, Tekst staropolski jako odmienny obiekt badań? W poszukiwaniu narzędzi opisu, „LingVaria” nr 2 (20), s. 235-250, [on-line:] http://dx.doi.org/10.12797/LV.20.2015. 20.18.

Milewski T., 1965, Językoznawstwo, Warszawa.

NKJP: Narodowy Korpus Języka Polskiego, [on-line:] nkjp.pl.

Opec B., 1522/2014, Żywot Pana Jezu Krysta (1522), wyd. W. Wydra, R. Wójcik, Poznań.

Pasoń A., 1976, Syntaktyczne sposoby wyrażania przyczyny w historii języka polskiego, Wrocław.

PAWElec R. (red.), 2015, Słownik zapomnianych wyrażeń funkcyjnych, Warszawa.

Petrov I.N., Twardzik W., 2014, Gdyby przysięgły człowiek widział kogo raniąc barzo, czyli o staropolskich imiesłowach nieodmiennych czasu teraźniejszego w funkcji biernej, „Język Polski” XCIV, s. 63-68.

RP: Rozmyślanie przemyskie. Transliteracja, transkrypcja, podstawa łacińska, niemiecki przekład, wyd. F. Keller i W. Twardzik, t. I-III, Weiher - Freiburg im Breisgau.

SAlONi Z., 1974, Klasyfikacja gramatyczna leksemów polskich, „Język Polski” LIV, s. 3-13.

Sовотка P., 2014a, Od zaimka do wyrażenia funkcyjnego. Dzieje prasłowiańskiego zaimka ${ }^{*}$ vbs-akъ i jego kontynuantów, [w:] A. Moroz, P. Sobotka, M. Żabowska (red.), Maiuscula linguistica. Studia in honorem professori Matthiae Grochowski sextuagesimo quinto dedicata, Warszawa, s. 141-161.

Sовотка P., 2014b, Partykuły greckie - pochodzenie i wybrane problemy opisu, [w:] K. Kleszczowa, A. Szczepanek (red.), Wyrażenia funkcyjne w perspektywie diachronicznej, synchronicznej i porównawczej, Katowice, s. 133-167.

Sовотка P., 2015a, 'Each of...' or 'Almost Each of...' The Origin and the Initial Function of the Suffix*-ak-in Depronominal, Deadjectival, and Denumeral Formations, [w:] I. Janyšková, H. Karlíková (red.), Etymological Research into Old Church Slavonic, „Studia Etymologica Brunensia", t. 18, Praha, s. 347-360.

Sовотка P., 2015b, Współdziałanie podsystemów języka w perspektywie badań etymologicznych. Znaczenie i rozwój słowiańskich zaimków ${ }^{\star} \mathrm{vb} \backslash$ akъ $i$ *edьnakъ, „Linguistica Copernicana" 12, s. 157-211, [on-line:] http://dx.doi.org/10.12775/LinCop.2015.007.

Sовотка P., 2017a, Jednostka opisu jezzyka dawnego, [w:] M. Pastuchowa, M. Siuciak (red.), Historia języka wXXI wieku - stan i perspektywy, Katowice.

Sовотка P., 2017b, Komentarz językowy a interpretacja i rozumienie tekstu dawnego, [w:] T. Mika, K. Borowiec, D. Masłej (red.), Jak wydawać teksty dawne, Poznań.

SPXVI: Słownik polszczyzny XVI wieku, t. I-IV, red. komitet redakcyjny, t. V-XVII, red. M.R. Meyenowa, t. XVIII-XXXIV, red. F. Pepłowski, t. XXXV-XXXVI, red. K. Mrowcewicz, P. Potoniec, Wrocław - Warszawa - Kraków 1966-2012.

SSTP: S. Urbańczyk (red.), Słownik staropolski, Kraków 1953-2002.

Szober S., 1923, Gramatyka języka polskiego, wyd. 2 zm. i uzup., Lwów - Warszawa.

TwARDZIK W., 1997, O uważniejszym aniżeli dotychmiast tekstu staropolskiego czytaniu i jakie z niego pożytki płyna rozprawa śliczna i podziwienia godna, Kraków. 
WAjszczuk J., 1997, System znaczeń w obszarze spójników polskich. Wprowadzenie do opisu, Warszawa.

Wajszczuk J., 2005, O metatekście, Warszawa.

Wajszczuk J., 2010, Functional Class (so Called „Part of Speech”) Assignment as a Kind of Meaning-Bound Word Syntactic Information, „Cognitive Studies / Études cognitives” 10, s. 15-33, [on-line:] https://doi.org/10.11649/cs.2010.001.

Wanicowa Z., 2009, Ignota, dubia, reperta. Czytać i rozumieć staropolszczyznę, Kraków.

Wróвel H., 1996, Nowa propozycja klasyfikacji syntaktycznej polskich leksemów, [w:] idem (red.), Studia z leksykologii i gramatyki języków slowiańskich. VI Polsko-Szwedzka Konferencja Slawistyczna, Mogilany 1-3 października 1995, Kraków, s. 53-60.

Zalizniak A.A., 2008, A Catalogue of Semantic Shifts: Towards a Typology of Semantic Derivation, [w:] M. Vanhove (red.), From Polysemy to Semantic Change. Towards a Typology of Lexical Semantic Associations, Amsterdam - Philadelphia, s. 217-232.

Zaron Z., 2009, Problemy składni funkcjonalnej, Warszawa.

ŻAвоwsкA M., 2015, O godzeniu przeciwieństw - funkcja wyrażeń jednocześnie $i$ zarazem w języku naturalnym oraz $w$ testowaniu hipotez semantycznych, „Linguistica Copernicana" 12, s. 71-105, [on-line:] http://dx.doi.org/10.12775/LinCop.2015.003.

Мельчук И.А., 1974, Опыт теории тингвистических моделей «Смысл-Текст». Семантика, синтаксис, Москва.

\section{Delimitation, decoding and classification of historical language units Summary}

The main goal of the article is to present different kinds of problems connected with the identification of the language units in Old and early Middle Polish texts, and with the various manifestations of their functional interpretation. The authors propose the term 'historical unit of language' that is understood in both dynamic and static aspects of diachrony. The major sources of these units are inherited expressions, borrowings and internal creations. The historical language unit is bilateral in nature and its semantic features consist of three dimensions: etymological, actual, and associative components. The article examines metatextual units and processes of metatextualization, as well as uses the example of Rozmyślanie przemyskie, Żywot Pana Jezu Krysta and other texts to show such problems as cohesion of the text and its comprehensiveness, especially in syntactic and utterance levels. In the second part of the article the authors present functional division of the Old Polish lexicon based on combinational and semantic characteristics of units in question, i.e. on those properties that are responsible for the tasks to be accomplished by a given class of expressions in making up a higher order unit, i.e. a syntagm. The authors centre on uninflected language units, proposing eight sentence classes and three discursive classes. Among them: uninflected participles, metapredicative operators, adverbs, infinitives, prepositions, uninflected pronominal substitutes of space and temporal expressions and whole sentences, conjunctions, particles and restrictors, contextualizators, connectors. 